\title{
Duodenal Iron Proteins in Idiopathic Hemochromatosis
}

\author{
Paul Whittaker, Barry S. Skikne, Ann M. Covell, Carol Flowers, Allan Cooke, Sean R. Lynch, and James D. Cook \\ Division of Hematology, Department of Medicine, Kansas University Medical Center, Kansas City, Kansas 66103
}

\begin{abstract}
This study was undertaken to assess the relationship between iron absorption and the concentration of duodenal iron proteins in normal subjects and patients with idiopathic hemochromatosis (IH). Biopsies were obtained endoscopically from the duodenum in 17 normal subjects, 3 of whom were mildly iron deficient, and 7 patients with untreated IH. The absorption of both heme and nonheme iron was increased in IH despite a 20-fold elevation in serum ferritin. Immunoassays using MAb were used to measure transferrin, $\mathrm{H}$-rich ferritin, and L-rich ferritin in mucosal samples. Mucosal transferrin concentrations in normal subjects did not correlate with either iron status or iron absorption, indicating that mucosal transferrin plays no physiological role in iron absorption. Mucosal transferrin was significantly lower in $\mathrm{IH}$, presumably because of a decrease in mucosal transferrin receptors. Mucosal $H$ and $L$ ferritin concentrations were directly related to body iron stores and inversely related to iron absorption in normal subjects. In IH, mucosal $\mathrm{H}$ and $\mathrm{L}$ ferritin failed to increase in parallel with the serum ferritin, but were appropriate for the level of iron absorption. The relationship of mucosal $\mathrm{H} / \mathrm{L}$ ferritin in IH did not differ from that observed in normal subjects. Our findings indicate that the major abnormality in duodenal iron proteins in IH is a parallel decrease in the concentration of $\mathrm{H}$ - and L-rich ferritin. It is not evident whether this is the result or the cause of the absorptive abnormality.
\end{abstract}

\section{Introduction}

Idiopathic hemochromatosis $(\mathrm{IH})^{1}$ is an inherited disorder of iron metabolism associated with progressive and frequently lethal accumulation of body iron. The characteristic feature of this metabolic disease is excessive absorption from a diet with a normal iron content. The mode of inheritance has been established as autosomal recessive (1). The allele responsible for IH is located on the short arm of chromosome 6 adjacent to the A-locus of the HLA complex $(2,3)$ and apparently lies between the HLB and HLA loci (4). There is a pronounced variation in the racial and geographic prevalence of the dis-

This work was presented in part at the American Society of Hematology Meetings, December 1987, Washington, DC.

Dr. Whittaker's present address is the Food and Drug Administration, Washington, DC. Address reprint requests to Dr. James D. Cook, Division of Hematology, Kansas University Medical Center, 39th and Rainbow, Kansas City, KS 66103. 1988.

Received for publication 2 May 1988 and in revised form 8 July

1. Abbreviations used in this paper: $\mathrm{IH}$, idiopathic hemachromatosis.

J. Clin. Invest.

(c) The American Society for Clinical Investigation, Inc. 0021-9738/89/01/0261/07 \$2.00

Volume 83, January 1989, 261-267 ease, which has only been reported in Caucasians. The incidence of the gene in the U. S. population is $5-6 \%$, with a disease frequency of $\sim 3$ per 1,000 (5). The proportion of homozygous individuals who ultimately develop clinical manifestations of the disease is still uncertain.

Numerous theories have been advanced to account for the excessive absorption of iron in IH, but the underlying mechanism is still unknown. Some investigators believe that the mucosal cell is intrinsically normal, but responds to abnormal kinetic or hormonal regulatory signals. Other investigators believe that the defect lies within the mucosal cell, involving some facet of mucosal uptake, storage, intracellular transport, or release of iron. Transferrin and ferritin, the key proteins of iron metabolism, have both been identified in the intestinal mucosal cell. This investigation was undertaken to examine the relationship between iron absorption, body iron stores, and the mucosal concentration of these proteins in normal subjects and patients with IH.

\section{Methods}

Subjects. Studies were performed in 17 normal volunteers and 7 patients with IH. All subjects gave written, informed consent before participating in the study, which was carried out in accordance with the procedures of the Human Subjects Committee at the University of Kansas Medical Center. The normal group included 10 men and 7 women, ranging in age from 22 to $48 \mathrm{yr}$. None had a history of disorders that might alter iron absorption from the gastrointestinal tract and all had normal hemoglobin levels and red cell indices. However, three of the women had depleted iron reserves, as defined by a serum ferritin $<10 \mu \mathrm{g} /$ liter. In certain analyses, these subjects were separated from the normal group to reflect the effect of mild iron deficiency.

The patients with IH included six men and one woman, aged 31-60 yr. The diagnosis of IH was based on the absence of known causes of secondary iron overload, together with a persistent elevation of the transferrin saturation $>70 \%$, a serum ferritin level $>600 \mu \mathrm{g} /$ liter, and a liver biopsy showing a marked increase in parenchymal iron. In addition, a liver nonheme iron concentration was determined in four of these patients and each measured $>600 \mu \mathrm{g} / \mathrm{g}$ wet weight. One of the subjects (subject 1, Table I) had been phlebotomized previously. A total of $13 \mathrm{~g}$ iron had been removed, but he had not been phlebotomized for $2 \mathrm{yr}$ before this study. The remaining six patients had never been treated.

Iron absorption measurements. Absorption values for heme and nonheme dietary iron were determined simultaneously from a standard hamburger meal using double radioiron labels. The test meal was eaten between 7 and 9 a.m. after an overnight fast and no further food or liquid was allowed for $4 \mathrm{~h}$. The meal consisted of ground beef (113 $\mathrm{g}$ ), a bun ( $53 \mathrm{~g}$ ), French fries ( $68 \mathrm{~g}$ ), and a milk shake ( $145 \mathrm{~g}$ ). The meal furnished $820 \mathrm{kcal}$ and contained $4.8 \mathrm{mg}$ of iron, of which $1.4 \mathrm{mg}$ was in the form of heme.

The heme and nonheme iron pools of the standard meal were tagged extrinsically (6-8) as follows. The heme iron fraction was labeled by adding $0.6 \mathrm{mg}$ iron and $3 \mu \mathrm{Ci}$ radioactivity as ${ }^{55} \mathrm{Fe}$-labeled hemoglobin to the ground beef immediately before the meal was served. Radioactive hemoglobin was prepared in a pathogen-free rabbit (9). The nonheme compartment was labeled by adding $0.1 \mathrm{mg}$ iron and $1 \mu \mathrm{Ci}$ radioactivity as ${ }^{59} \mathrm{FeCl}_{3}$ in $0.5 \mathrm{ml} 0.01 \mathrm{~N} \mathrm{HCl}$ to the bun. 
Table I. Iron Status Measurements in Normal, Iron-deficient, and Hemochromatotic Subjects

\begin{tabular}{|c|c|c|c|c|c|c|c|c|c|}
\hline \multirow[b]{3}{*}{ Normal } & \multirow[b]{3}{*}{ Sex/Age } & \multirow[b]{3}{*}{ Serum iron } & \multirow[b]{3}{*}{$\begin{array}{l}\text { Transferrin } \\
\text { saturation }\end{array}$} & \multirow[b]{3}{*}{$\begin{array}{l}\text { Serum } \\
\text { ferritin }\end{array}$} & & & \multicolumn{3}{|c|}{ Mucosal proteins } \\
\hline & & & & & \multicolumn{2}{|c|}{ Absorption } & \multirow[b]{2}{*}{ Transferrin } & \multicolumn{2}{|c|}{ Ferritin } \\
\hline & & & & & Nonheme & Heme & & L-rich & H-rich \\
\hline & $y r$ & $\mu g / d l$ & $\%$ & $\mu g / l i t e r$ & \multicolumn{2}{|c|}{$\%$} & \multicolumn{3}{|c|}{$n g / m g$ protein } \\
\hline 1 & $F / 25$ & 75 & 20 & 17 & 21.0 & 53.7 & 985 & 117 & 102 \\
\hline 2 & $\mathrm{M} / 31$ & 77 & 27 & 26 & 29.3 & 49.0 & 706 & 33 & 23 \\
\hline 3 & $F / 48$ & 95 & 22 & 28 & 9.6 & 45.7 & 2,434 & 182 & 200 \\
\hline 4 & $\mathrm{M} / 31$ & 89 & 25 & 29 & 7.9 & 39.0 & 1,328 & 115 & 59 \\
\hline 5 & $F / 26$ & 66 & 20 & 36 & 5.9 & 21.4 & 3,750 & 392 & 235 \\
\hline 6 & $M / 28$ & 39 & 10 & 38 & 3.4 & 38.0 & 713 & 66 & 136 \\
\hline 7 & $M / 28$ & 87 & 24 & 64 & 1.8 & 18.6 & 808 & 71 & 49 \\
\hline 8 & $F / 35$ & 52 & 18 & 69 & 2.7 & 28.9 & 632 & 86 & 66 \\
\hline 9 & $M / 27$ & 94 & 29 & 76 & 3.8 & 20.5 & 894 & 458 & 202 \\
\hline 10 & $M / 26$ & 70 & 22 & 96 & 2.2 & 30.1 & 1,148 & 268 & 183 \\
\hline 11 & $\mathrm{M} / 35$ & 75 & 24 & 121 & 3.2 & 10.4 & 2,674 & 300 & 244 \\
\hline 12 & $M / 29$ & 78 & 23 & 135 & 1.3 & 17.7 & 2,826 & 244 & 227 \\
\hline 13 & $\mathrm{M} / 36$ & 125 & 50 & 147 & 1.0 & 26.1 & 762 & 307 & 108 \\
\hline 14 & $\mathbf{M} / 27$ & 133 & 43 & 239 & 0.8 & 35.8 & 1,000 & 386 & 81 \\
\hline Mean* & & 83 & 26 & 61 & 3.8 & 28.4 & 1,230 & 167 & 112 \\
\hline$-1 \mathrm{SE}$ & & 76 & 23 & 49 & 2.8 & 25.1 & 1,048 & 135 & 93 \\
\hline$+1 \mathrm{SE}$ & & 90 & 29 & 75 & 5.1 & 32.1 & 1,443 & 208 & 136 \\
\hline \multicolumn{10}{|c|}{ Iron deficiency } \\
\hline 1 & $F / 22$ & 23 & 6 & 2 & 15.3 & 44.3 & 880 & 26 & 34 \\
\hline 2 & $F / 38$ & 55 & 12 & 4 & 21.9 & 52.5 & 833 & 19 & 15 \\
\hline 3 & $F / 28$ & 68 & 20 & 9 & 31.1 & 47.9 & 1,328 & 95 & 74 \\
\hline Mean* & & 49 & 13 & 4 & 21.8 & 48.1 & 991 & 36 & 34 \\
\hline$-1 \mathrm{SE}$ & & 36 & 9 & 3 & 17.8 & 45.8 & 855 & 22 & 21 \\
\hline$+1 \mathrm{SE}$ & & 62 & 17 & 6 & 26.8 & 50.5 & 1,148 & 59 & 53 \\
\hline \multicolumn{10}{|c|}{ Idiopathic hemochromatosis } \\
\hline 1 & $\mathbf{M} / 47$ & 188 & 100 & 210 & 25.2 & 84.2 & 536 & 180 & 41 \\
\hline 2 & $\mathbf{M} / 30$ & 215 & 100 & 617 & 9.8 & 43.8 & 471 & 71 & 61 \\
\hline 3 & $\mathrm{M} / 36$ & 290 & 100 & 1,586 & $2.3^{\ddagger}$ & $12.6^{\ddagger}$ & 393 & 412 & 364 \\
\hline 4 & $\mathrm{~F} / 54$ & 174 & 76 & 1,603 & 1.5 & 30.2 & 368 & 206 & 73 \\
\hline 5 & $\mathrm{M} / 31$ & 170 & 89 & 2,700 & 5.0 & 32.4 & 1,902 & 1,018 & 689 \\
\hline 6 & $\mathbf{M} / 59$ & 175 & 88 & 2,883 & 32.9 & 77.3 & 213 & 76 & 30 \\
\hline 7 & $\mathrm{M} / 60$ & 200 & 98 & 3,031 & 12.4 & 69.8 & 483 & 88 & 44 \\
\hline Mean* & & 202 & 93 & 1,340 & 9.5 & 51.9 & 494 & 185 & 93 \\
\hline$-1 \mathrm{SE}$ & & 186 & 90 & 923 & 6.0 & 43.1 & 384 & 127 & 59 \\
\hline$+1 \mathrm{SE}$ & & 218 & 96 & 1,946 & 15.1 & 62.4 & 635 & 268 & 146 \\
\hline
\end{tabular}

* Geometric means except serum iron and transferrin saturation. ${ }^{\ddagger}$ Determined by incorporated red cell radioactivity.

Iron absorption was measured by a combination of whole-body counting and incorporated red cell radioactivity. The absorption of ${ }^{59} \mathrm{Fe}$ was measured $14 \mathrm{~d}$ after test dose administration in a shadowshield whole-body counter using longitudinal scan geometry (10). Absorption of the ${ }^{55} \mathrm{Fe}$ label was determined from the ratio of ${ }^{55} \mathrm{Fe} /{ }^{59} \mathrm{Fe}$ activity in circulating red blood cells obtained $14 \mathrm{~d}$ after the test dose. Radioactivity measurements were performed on duplicate 10-ml samples of whole blood using a modification of the method of Eakins and Brown (11). One of the patients with IH (subject 3, Table 1) could not be accommodated in the whole body counter. Absorption of ${ }^{59} \mathrm{Fe}$ and ${ }^{55} \mathrm{Fe}$ in this patient was calculated on the basis of blood volume esti- mated from height and weight (12) and an assumed red cell incorporation for absorbed radioactivity of $80 \%$. Sufficient counts were obtained on digested blood samples to reduce the net counting error for each isotope to $\pm 2 \%$ or less in subjects absorbing $>1 \%$ of the test dose.

Intestinal biopsies. Multiple duodenal biopsies were obtained by fiberoptic endoscopy in all subjects. The biopsy samples were placed directly into calcium and magnesium-free HBSS (Gibco Laboratories, Grand Island, New York) buffered with 0.005 mol/liter Tris-HCl, $\mathrm{pH}$ 7.4. The mucosal cell preparation was kept on crushed ice throughout the processing procedure. The specimen was rinsed gently, resuspended in $2.5 \mathrm{ml}$ of buffer, and mechanically vibrated with a vortex 
mixer for 1 min to dislodge the mucosal cells $(13,14)$. After removing the cytoskeleton, the cell suspension was pelleted by centrifugation at $1,000 \mathrm{~g}$ for $5 \mathrm{~min}$ and resuspended in $2.5 \mathrm{ml}$ fresh buffer. The cells were then sonicated for two 30 -s periods and the debris removed by a final centrifugation at $10,000 \mathrm{~g}$ for $10 \mathrm{~min}$. The supernatant was stored at $-20^{\circ} \mathrm{C}$ for later protein and ELISA measurements. Protein determinations were performed by the method of Lowry et al. (15) using BSA as the standard.

Immunoassays. The concentration of transferrin and $\mathrm{L}$ and $\mathrm{H}$-rich ferritin was measured by ELISA with specific MAb. The assay for $\mathrm{L}$ ferritin (basic isoferritin) was developed using recrystalized human liver ferritin (16). This assay has a working range of 1 to $100 \mu \mathrm{g} /$ liter and a sensitivity of $0.5 \mu \mathrm{g}$ ferritin/liter. The ELISA for transferrin has also been recently described (17). This assay is standardized with purified human transferrin (T-2252; Sigma Chemical Co., St. Louis, MO). Measurements on human serum have demonstrated a close correlation between values obtained by ELISA and measurement of total iron-binding capacity (17).

The assay for $\mathrm{H}$ ferritin (acidic isoferritin) was developed using human heart as the ferritin source. The ferritin was purified by ultracentrifugation and gel filtration on Sepharose 6B (Pharmacia Fine Chemicals, Piscataway, NJ) (18). Purity was confirmed by PAGE in $5 \%$ gels at pH 7.8 (19). This heart ferritin preparation which was used for the development of MAb, contained predominantly acidic isoferritins when examined by isoelectric focusing on $4 \%$ polyacrylamide gels after being stained for protein (20). MAb were prepared by the subcutaneous injection of $100 \mu \mathrm{g}$ ferritin protein in CFA into 6-wk-old male $\mathrm{Balb} / \mathrm{c}$ mice. The animals were boosted with the same quantity of protein on two subsequent occasions at 2-wk intervals and again $3 \mathrm{~d}$ before fusion. Spleen cells were then fused with a murine myeloma line (P3/X63-AG8-6.5.3). Hybridomas were selected in hypoxanthine aminopterin thymidine medium and screened for antibody production by assaying the supernatant in microtiter plates coated with purified heart ferritin. Only hybrid cultures failing to react with recrystalized liver ferritin were selected. Hybrid cultures positive for antiferritin were cloned three times by limiting dilution. Cultures were expanded in flasks and injected intraperitoneally into pristane-primed Balb/c mice for harvesting of ascitic fluid 10-21 d later.

The ELISA for $\mathrm{H}$ ferritin was established using MAb for the solidphase and indicator reagent. The performance characteristics of the assay were virtually identical to those described previously for $L$ ferritin (16). Recrystalized human liver ferritin was completely nonreactive in the assay for $\mathrm{H}$ ferritin at any concentration. However, $18 \%$ of the heart ferritin used to prepare the monoclonal reagents could initially be detected in the assay for $L$ ferritin. The heart ferritin was then further purified to remove any L-type ferritin, either with HPLC or by adsorbing with an excess of MAb against $L$ ferritin that had been immobilized on Sepharose 4B. The proportion of $\mathrm{H}$ ferritin reacting in the $\mathrm{L}$ ferritin assay was reduced to $5.2 \%$ by both purification methods. This repurified material was used as the standard for the $\mathrm{H}$ ferritin assay. The small degree of continuing cross-reactivity of the heart ferritin standard for monoclonals prepared against $L$ ferritin presumably represents the minimum $\mathrm{L}$ subunit composition of $\mathrm{H}$-rich ferritin (21).

In all three ELISAs, background and six dilutions of the standard were measured in triplicate in each 96-well microtiter plate. All unknowns and quality control sera were assayed in triplicate. Two quality control sera obtained from normal subjects and stored at $-20^{\circ} \mathrm{C}$ were included in each assay run of transferrin and ferritin. Preliminary studies showed that recovery of purified transferrin, $L$ ferritin, and $H$ ferritin, when added to homogenates of human mucosal cells, ranged from 95 to $105 \%$. With each assay system, serial dilutions of mucosal homogenates gave absorbance readings that varied in parallel with the standard curve.

A preliminary study was performed in normal subjects to determine whether the level of the duodenum from which the biopsy was obtained affected the concentration of iron proteins (Table II). One or two biopsies were obtained from the proximal, middle, and distal
Table II. Comparison of Mucosal Protein Concentrations Obtained from Three Duodenal Segments of Eight Subjects*

\begin{tabular}{lccccc}
\hline & \multicolumn{3}{c}{ Duodenal segment $^{*}$} \\
\cline { 2 - 4 } Mucosal protein & Proximal & Middle & Distal & $F$ test & $P$ value \\
\hline \multirow{5}{*}{ Transferrin } & 754 & 794 & 796 & 0.181 & 0.84 \\
& $(599-816)$ & $(648-972)$ & $(672-942)$ & & \\
L Ferritin & 69 & 49 & 64 & 0.280 & 0.76 \\
& $(41-72)$ & $(38-62)$ & $(50-81)$ & & \\
H Ferritin & 37 & 36 & 47 & 0.378 & 0.69 \\
& $(28-49)$ & $(27-47)$ & $(40-56)$ & &
\end{tabular}

* 18 of 24 biopsies were obtained in duplicate.

‡ Geometric mean ( $\pm 1 \mathrm{SE})$.

duodenum in each of six normal subjects and two patients with $\mathrm{IH}$. Analysis of variance showed no significant effect of the level of the biopsy on the concentration of any of the iron related proteins.

Serum ferritin was measured in the $\mathrm{L}$ ferritin monoclonal assay as described previously (16). Serum iron was measured by an electrochemical technique (22). Total iron-binding capacity was measured by the ICSH Panel method using light magnesium carbonate as the absorbent (23).

Data analysis. Percentage iron absorption data (24) and transferrin and $\mathrm{L}$ and $\mathrm{H}$ ferritin values in mucosal homogenates showed a highly skewed distribution. Consequently, the original values were converted to logarithms for statistical analysis and the results were reconverted as antilogs to recover the original units. All values for iron absorption and iron-related proteins in mucosal homogenates are therefore geometric means. Similarly, all statistical analyses including $t$ tests, analysis of variance, correlation, and regression analysis were performed on the logarithmically transformed data.

\section{Results}

The measurements of iron status, iron absorption, and mucosal proteins are listed in Table I. In normal subjects, absorption of nonheme and heme iron averaged 3.8 and $28.4 \%$, respectively. In the iron-depleted subjects, absorption was sharply increased to 21.8 and $48.1 \%$, respectively. In $\mathrm{IH}$, mean absorption values for nonheme $(9.5 \%)$ and heme $(51.9 \%)$ iron were both higher than in normal individuals, but the differences were not statistically significant.

Mucosal transferrin, which averaged $1,230 \mathrm{ng} / \mathrm{mg}$ protein in normal subjects, was reduced to $494 \mathrm{ng} / \mathrm{mg}$ in IH $(t=3.174$, $P<0.005$ ). Only one of the seven patients with IH had a mucosal transferrin concentration within the range observed in iron-replete normal subjects. Importantly, no significant difference in mucosal transferrin was observed between normal subjects with depleted and those with normal iron stores.

The concentration of mucosal $L$ ferritin ranged from 33 to $458 \mathrm{ng} / \mathrm{mg}$ protein with a geometric mean of $167 \mathrm{ng} / \mathrm{mg}$ in the normal subjects. The mean concentration of $\mathrm{H}$ ferritin was somewhat lower, $112 \mathrm{ng} / \mathrm{mg}$ protein. Both isoferritin fractions were reduced by $\sim 75 \%$ in iron-depleted controls. In IH, mean mucosal $\mathrm{L}$ ferritin (185 ng/mg protein) and $\mathrm{H}$ ferritin (93 $\mathrm{ng} / \mathrm{mg}$ protein) were similar to the levels observed in iron-replete normal subjects.

Highly significant correlations were observed between measurements of iron status, iron absorption, and the concen- 
Table III. Correlation Coefficients between Measurements of Iron Status, Absorption, and Mucosal Cell Iron Proteins in Normal and Iron-deficient Subjects

\begin{tabular}{|c|c|c|c|c|c|c|c|c|}
\hline & $\begin{array}{c}\text { Serum } \\
\text { iron }\end{array}$ & $\begin{array}{l}\text { Iron-binding } \\
\text { capacity }\end{array}$ & $\begin{array}{l}\text { Transferrin } \\
\text { saturation }\end{array}$ & $\begin{array}{l}\text { Serum } \\
\text { ferritin }\end{array}$ & $\begin{array}{l}\text { Nonheme } \\
\text { absorption }\end{array}$ & $\begin{array}{c}\text { Heme } \\
\text { absorption }\end{array}$ & $\begin{array}{l}\text { Mucosal } \\
\text { transferrin }\end{array}$ & $\begin{array}{l}\text { L-rich } \\
\text { ferritin }\end{array}$ \\
\hline Iron-binding capacity & -0.443 & & & & & & & \\
\hline Transferrin saturation & $0.938^{*}$ & $-0.668^{*}$ & & & & & & \\
\hline Serum ferritin & $0.664^{*}$ & $-0.678^{*}$ & $0.702^{*}$ & & & & & \\
\hline Nonheme absorption & $-0.488^{\ddagger}$ & $0.474^{\ddagger}$ & $-0.562^{\ddagger}$ & $-0.847^{*}$ & & & & \\
\hline Heme absorption & -0.188 & $0.447^{\ddagger}$ & -0.257 & $-0.641^{*}$ & $0.643^{*}$ & & & \\
\hline Mucosal transferrin & 0.082 & 0.055 & -0.033 & 0.163 & -0.052 & -0.429 & & \\
\hline L-rich ferritin & $0.625^{*}$ & $-0.519^{\ddagger}$ & $0.620^{*}$ & $0.773^{*}$ & $-0.624^{*}$ & $-0.583^{\ddagger}$ & $0.509^{\ddagger}$ & \\
\hline H-rich ferritin & 0.239 & -0.271 & 0.217 & $0.605^{*}$ & $-0.480^{\ddagger}$ & $-0.580^{\ddagger}$ & $0.630^{*}$ & $0.856^{*}$ \\
\hline
\end{tabular}

${ }^{*} P<0.01 ;{ }^{\ddagger} P<0.05$.

trations of mucosal iron proteins in normal subjects. The correlation coefficients for the composite group of 17 control subjects are listed in Table III. Relating iron status to iron absorption, the highest correlation was observed between serum ferritin and nonheme iron absorption $(r=-0.847)$. The correlation between serum ferritin and heme iron absorption was lower, but still highly significant $(r=-0.643)$. Of the mucosal iron proteins, L ferritin was highly correlated with both serum ferritin $(r=0.773)$ and nonheme iron absorption $(r=-0.624)$. These correlations were lower with $\mathrm{H}$ ferritin, but the concentrations of two isoferritin fractions were closely related to each other $(r=0.860)$. No significant correlation was observed between the concentration of mucosal transferrin and either serum ferritin or iron absorption.

The changes in iron absorption and mucosal iron proteins in $\mathrm{IH}$ are best examined in relationship to the correlations observed in normal subjects. The elevation in nonheme iron absorption in IH is more apparent when examined in relationship to their marked elevation in serum ferritin (Fig. 1). Based on the relationship between serum ferritin and nonheme iron absorption in normal subjects, a serum ferritin of $10-15 \mu \mathrm{g} /$ liter would be predicted at the mean absorption of $9.5 \%$ in IH. This is two orders of magnitude lower than the observed mean serum ferritin of $1,340 \mu \mathrm{g} /$ liter. İron absorption in untreated $\mathrm{IH}$ is thus markedly elevated when related to body iron reserves.

On the other hand, the concentration of mucosal $L$ ferritin in IH was appropriate for the level of nonheme iron absorption (Fig. 2), but far below the concentration that would have been predicted from the serum ferritin level (Fig. 3). Based on the relationship observed in normal subjects, one thus would predict a mucosal $\mathrm{L}$ ferritin concentration in patients with $\mathrm{IH}$ of $1,060 \mathrm{ng} / \mathrm{mg}$ protein at a mean serum ferritin of $1,340 \mu \mathrm{g} / \mathrm{ml}$, whereas a mean concentration of $185 \mathrm{ng} / \mathrm{mg}$ was observed. Importantly, there was no significant alteration in the relationship between $\mathrm{L}$ and $\mathrm{H}$ ferritin in patients with $\mathrm{IH}$ (Fig. 4). The ratio of $\mathrm{L} / \mathrm{H}$ ferritin averaged 1.72 in 14 iron-replete subjects and 2.28 in $\mathrm{IH}(P=0.23)$.

\section{Discussion}

The central disturbance in IH is excessive absorption of dietary iron despite expanded body iron stores (25-27). By simultaneously labeling the nonheme and heme iron compartments of the hamburger meal used in this study, it is possible to obtain quantitative estimates of total absorbed dietary iron. The iron-replete men in our study absorbed an average of $2.9 \%$ nonheme and $26.0 \%$ heme iron. Assuming a daily intake of 18 mg dietary iron with $10 \%$ or $1.8 \mathrm{mg}$ in the form of heme, these men absorbed $0.47 \mathrm{mg}$ nonheme and $0.47 \mathrm{mg}$ heme iron. The combined daily absorption of $0.94 \mathrm{mg}$ iron agrees closely with the current estimate for daily basal iron loss in normal men of $0.9 \mathrm{mg}$ (28). When these calculations are applied to the six male patients with IH, absorption values of $1.67 \mathrm{mg}$ for nonheme and $0.81 \mathrm{mg}$ for heme iron are obtained or a total of 2.48 mg daily. Assuming that basal iron loss in IH is similar to that in normal subjects, these patients are accumulating excess iron from the diet at a rate of $1.5 \mathrm{mg}$ daily or $\sim 0.5 \mathrm{~g} / \mathrm{yr}$, despite the marked elevation in their transferrin saturation and serum ferritin.

Several workers have described the presence of a protein in the intestinal mucosal cells of small laboratory animals that is similar, if not identical to circulating transferrin (29-31). Quantitative immunologic assays performed on homogenates of rat mucosal cells demonstrated that the concentration of mucosal transferrin varies directly with radioiron uptake by the mucosa (14). Based on studies in the rat, Huebers and co-workers have suggested that transferrin functions as a shuttle protein in iron absorption by transporting iron from the lumen into the mucosal cell (32). However, there are many observations that argue against a role for transferrin in the

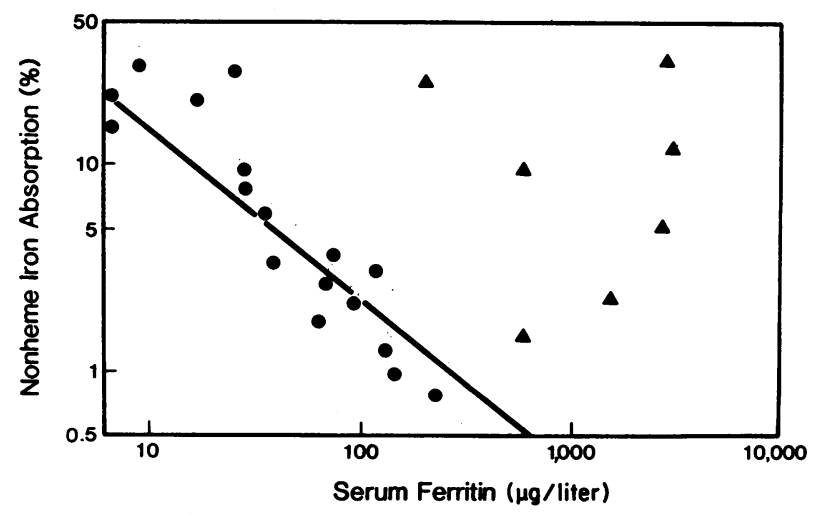

Figure 1. Relationship between serum ferritin and iron absorption in (๖) normal and (৯) IH subjects. 


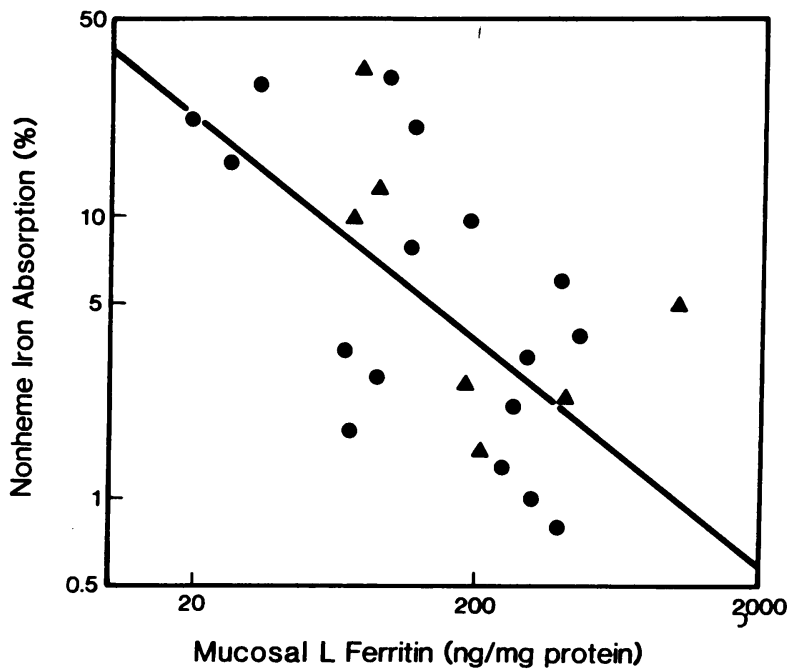

Figure 2. Relationship between iron absorption and mucosal L-rich

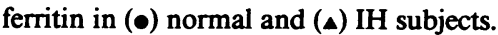

mucosal uptake of luminal iron (33). The addition of transferrin to luminal fluid in tied-off segments of mouse intestine was found to reduce absorption of iron from ferric nitrilotriacetate (34). No uptake by segments of human small intestinal mucosa could be demonstrated when incubated with saturated serum transferrin in vitro (35). Efforts to demonstrate transferrin receptors on the luminal membrane of intestinal mucosal cells have been unsuccessful $(36,37)$. A recent study suggests that immunoreactive mucosal transferrin may be derived from submucosal tissue (38). At this time, neither the origin nor the function of mucosal transferrin is known.

This study is the first in which transferrin has been assayed quantitatively in samples of human mucosa. In contrast to observations in the rat (14), we were unable to demonstrate a relationship between mucosal transferrin and measurements of either iron status or iron absorption in normal subjects. It is possible that mucosal transferrin concentrations increase only when iron deficiency is severe enough to induce an elevation in circulating transferrin. Nevertheless, because our control subjects encompass a broad range in iron absorption and iron status, it is unlikely that mucosal transferrin plays a physiologic role in regulating mucosal iron transport, at least in the absence of severe iron deficiency.

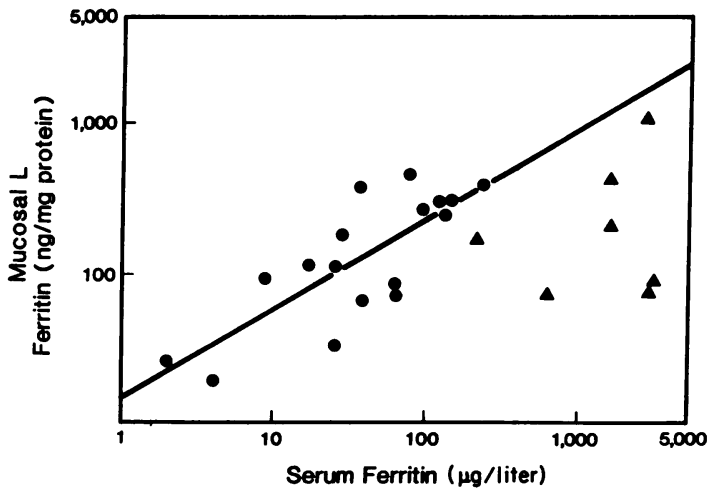

Figure 3. Relationship between the concentration of serum ferritin

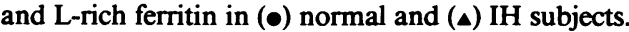

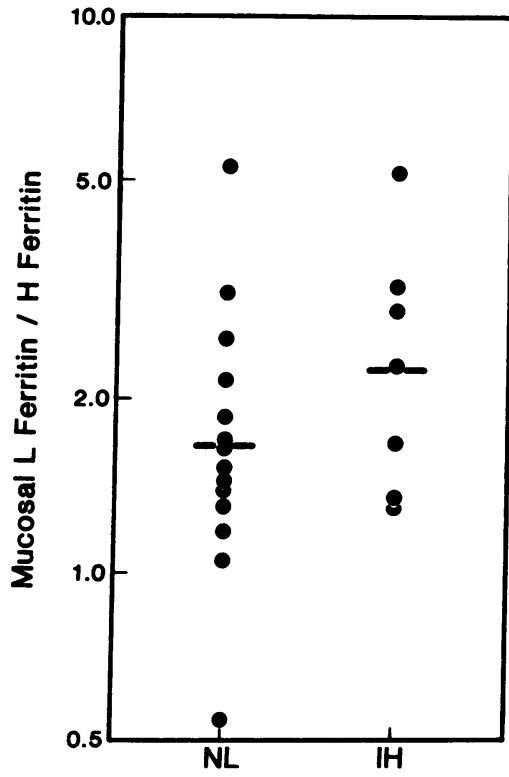

Figure 4. Ratio of $\mathrm{H} / \mathrm{L}$ ferritin in duodenal mucosa from normal subjects (NL) and patients with idiopathic hemochromatosis (IH).

One of the main objectives of our study was to determine whether an elevation in mucosal transferrin could explain the facilitated absorption in patients with IH. Not only did we fail to demonstrate a positive relationship between mucosal transferrin and iron absorption in normal subjects, but patients with IH who absorbed increased quantities of iron showed a significant decrease, rather than elevation, in mucosal transferrin. Transferrin receptors have recently been demonstrated on the basolateral portion of the mucosal cell in human subjects (37). The lower levels of mucosal transferrin observed in IH suggest that it is derived predominantly from the circulation and reflects a decreased expression of transferrin receptors. In support of this contention, Sciot et al. (39) have recently reported that transferrin receptors could not be detected immunologically in hepatocytes in 19 of 22 patients with IH and severe iron overload, whereas they were invariably present in normal controls. A sustained elevation in serum iron and transferrin saturation presumably leads to a downregulation in the transferrin receptor in parenchymal cells, including the intestinal mucosa. Our findings support the suggestion that neither transferrin nor its receptor is directly involved in iron absorption, but as in other body cells, these proteins are concerned with acquiring iron for cellular growth and development (37).

The role of mucosal ferritin in iron absorption has been debated since the mucosal block theory was first advanced (40). The biochemistry of ferritin has been studied intensively in recent years $(41,42)$. It is now known that ferritins purified from different human tissues vary in their electrophoretic mobility and surface charge. These differences result from variations in the 24 protein subunits that make up the apoferritin protein shell (43). Two separate subunits, designated $H$ and $L$, that differ in size, amino acid composition, and charge have been identified. Both are derived from multigene families, although there is still no convincing evidence that more than one $H$ chain and one $L$ chain is expressed (44). Ferritin purified from human liver is composed predominantly of $\mathrm{L}$ subunits, whereas ferritin derived from heart is composed predominantly of $\mathbf{H}$ subunits. $\mathrm{L}$ ferritin appears to function primarily as an iron storage protein within the cell, whereas an addi- 
tional role for $\mathrm{H}$ ferritin has been proposed in immunosuppression $(45,46)$, myelopoietic regulatory activity $(47,48)$, and heme synthesis $(49,50)$.

An impairment in ferritin synthesis in the intestinal mucosal cell has been proposed as the basic defect in IH $(51,52)$. Halliday and co-workers (26) first reported that the concentration of mucosal ferritin was approximately twofold higher than normal in IH and much lower than would have been predicted from their elevated serum ferritin. These workers also observed that mucosal ferritin was low in relation to serum ferritin in two patients with transfusional iron overload and they suggested that a decrease in duodenal ferritin is a feature of iron overload regardless of the cause. However, a more appropriate comparison might be made between patients with IH and those with secondary iron overload from excessive oral intake rather than from iron derived from red cell transfusions, which localizes predominantly in the reticuloendothelial system. Recently we had the opportunity to study such a patient. A 65-yr-old woman had ingested one tablet of ferrous sulfate daily for $>40 \mathrm{yr}$. She was observed to have abnormal liver enzymes during an evaluation for osteoporosis. Her serum iron was $134 \mu \mathrm{g} / \mathrm{dl}$, her total iron binding capacity was $195 \mu \mathrm{g} / \mathrm{dl}$, her transferrin saturation was $69 \%$, and her serum ferritin was $1,991 \mu \mathrm{g} /$ liter. The presence of IH could not be detected in other family members either by history or by laboratory examination. A liver biopsy showed a pronounced increase in hepatocellular iron, but there was no evidence of fibrosis. Absorption of nonheme and heme iron was 0.5 and $3.4 \%$, respectively. The concentration of mucosal $\mathrm{L}$ ferritin was $951 \mathrm{ng} / \mathrm{mg}, \mathrm{H}$ ferritin was $368 \mathrm{ng} / \mathrm{mg}$, and mucosal transferrin was $1,346 \mathrm{ng} / \mathrm{mg}$ protein. The mucosal concentration of $\mathrm{L}$ ferritin therefore approached the predicted value of $1,339 \mathrm{ng} / \mathrm{mg}$ based on the relationship between serum ferritin and mucosal ferritin in normal subjects (Fig. 3) and was far above the mean of $185 \mathrm{ng} / \mathrm{mg}$ protein observed in our patients with IH.

Recent studies of ferritin gene synthesis have provided circumstantial evidence that ferritin may be involved in the absorptive abnormality in IH. Studies of the chromosomal distribution of the $\mathrm{H}$ ferritin subunit sequence have shown that the $\mathrm{H}$ gene is present on at least seven different chromosomes (53). The detection of an $\mathrm{H}$ ferritin sequence at $6 \mathrm{P} 12$ in close proximity to the HLA locus provides some circumstantial evidence for involvement of the $\mathrm{H}$ subunit in $\mathrm{IH}$. In this study, however, no disturbance in the relationship between L-rich ferritin and $\mathrm{H}$-rich ferritin could be detected. This agrees with the previous findings by Halliday and co-workers (26), who reported that the mucosal isoferritin profile in IH does not differ significantly from that seen in normal subjects. Our failure to detect a disturbance in the ratio of $\mathrm{H}$-rich and L-rich ferritins in IH suggests that if duodenal ferritin plays a role in the pathogenesis of $\mathrm{IH}$, it is associated with a parallel disturbance in both $\mathrm{H}$ - and L-rich ferritin molecules. It is also not clear whether the lower concentration of mucosal ferritin relative to serum ferritin in $\mathrm{IH}$ results from a primary defect in the regulation of ferritin synthesis or from a secondary decrease in mucosal iron storage because of inappropriately accelerated transfer of absorbed iron to the circulation.

\section{Acknowledgments}

This work was supported in part by National Institutes of Health grant DK-39246.

\section{References}

1. Saddi, R., and J. Feingold. 1974. Idiopathic haemochromatosis: an autosomal recessive disease. Clin. Genet. 5:234-241.

2. Simon, M., M. Bourel, B. Genetet, and R. Fauchet. 1977. Idiopathic hemochromatosis. Demonstration of recessive transmission and early detection by family HLA typing. N. Engl. J. Med. 297:1017-1021.

3. Dadone, M. M., J. P. Kushner, C. Q. Edwards, D. T. Bishop, and M. H. Skolnick. 1982. Hereditary hemochromatosis. Analysis of laboratory expression of the disease by genotype in 18 pedigrees. Am. J. Clin. Pathol. 78:196-207.

4. Edwards, C. Q., L. M. Griffen, M. M. Dadone, M. H. Skolnick, and J. P. Kushner. 1986. Mapping the locus for hereditary hemochromatosis: localization between HLA-B and HLA-A. Am. J. Hum. Genet. 38:805-811.

5. Cartwright, G. E., C. Q. Edwards, K. Kravitz, M. Skolnick, D. B. Amos, A. Johnson, and L. Buskjaer. 1979. Hereditary hemochromatosis. Phenotypic expression of the disease. N. Engl. J. Med. 301:175179.

6. Hallberg, L., and E. Bjorn-Rasmussen. 1972. Determination of iron absorption from whole diet. A new two-pool model using two radioiron isotopes given as haem and non-haem iron. Scand. J. Haematol. 9:193-197.

7. Cook, J. D., M. Layrisse, C. Martinez-Torres, R. Walker, E. Monsen, and C. A. Finch. 1972. Food iron absorption measured by an extrinsic tag. J. Clin. Invest. 51:805-815.

8. Layrisse, M., C. Martinez-Torres, J. D. Cook, R. Walker, and C. A. Finch. 1973. Iron fortification of food: its measurement by the extrinsic tag method. Blood. 41:333-352.

9. Dawson, R. B., S. Rafal, and L. R. Weintraub. 1970. Absorption of hemoglobin iron: the role of xanthine oxidase in the intestinal heme-splitting reaction. Blood. 35:94-103.

10. Cook, J. D., H. E. Palmer, K. G. Pailthorp, and C. A. Finch. 1970. The measurement of iron absorption by whole-body counting. Phys. Med. Biol. 15:467-473.

11. Eakins, J. D., and D. A. Brown. 1966. An improved method for the simultaneous determination of iron- 55 and iron- 59 in blood by liquid scintillation counting. Int. J. Appl. Radiat. Isot. 17:391-397.

12. Wennesland, R., E. Brown, J. Hopper, Jr., J. L. Hodges, Jr., O. E. Guttentag, K. G. Scott, I. N. Tucker, and B. Bradley. 1959. Red cell, plasma and blood volume in healthy men measured by radiochromium $(\mathrm{Cr} 51)$ cell tagging and hematocrit. Influence of age, somatotype and habits of physical activity on variance after regression of volumes to height and weight combined. J. Clin. Invest. 38:10651077.

13. Momtazi, L., and V. Herbert. 1973. Intestinal absorption using vibration obtained small bowel epithelial cells of the rat: folate absorption. Am. J. Clin. Nutr. 26:23-29.

14. Savin, M. A., and J. D. Cook. 1978. Iron transport by isolated rat intestinal mucosal cells. Gastroenterology. 75:688-694.

15. Lowry, O. H., N. J. Rosebrough, A. L. Farr, and R. J. Randall. 1951. Protein measurement with the Folin phenol reagent. J. Biol. Chem. 193:265-275.

16. Flowers, C. A., M. Kuizon, J. L. Beard, B. S. Skikne, A. M. Covell, and J. D. Cook. 1986. A serum ferritin assay for prevalence studies of iron deficiency. Am. J. Hematol. 23:141-151.

17. El Guindi, M., B. S. Skikne, A. M. Covell, and J. D. Cook. 1988. An immunoassay for human transferrin. Am. J. Clin. Nutr. 47:37-41.

18. Jones, B. M., and M. Worwood. 1978. An immunoradiometric assay for the acidic ferritin of human heart: application to human tissues, cells and serum. Clin. Chim. Acta. 85:81-88.

19. Worwood, M. 1980. Serum ferritin. In Methods in Hematology. Vol. 1. J. D. Cook, editor. Churchill Livingstone, Inc., London. 59-89.

20. Covell, A. M., D. E. Einspahr, B. S. Skikne, and J. D. Cook. 1987. Specific binding of acidic isoferritins to erythroleukemia K562 cells. J. Lab. Clin. Med. 110:784-790. 
21. Arosio, P., S. Levi, E. Gabri, G. Rugerri, C. Iacobello, A. Albertini, and F. Cavanna. 1984. Heterogeneity of ferritin, II: immunological aspects. In Ferritins and Isoferritins as Biochemical Markers. Vol. 19. A. Albertini, P. Arosio, E. Chiancone, and J. Drysdale, editors. Elsevier Science Publishers, Amsterdam. 33-47.

22. Skikne, B. S. 1987. A commercial electrochemical method evaluated for measurement of iron status. Clin. Chem. 33:1645-1647.

23. Bothwell, T. H., M. E. Conrad, J. D. Cook, J. Fielding, L. Hallberg, G. Izak, M. Layrisse, and W. N. M. Ramsey. 1978. The measurement of total and unsaturated iron-binding capacity in serum. Br. J. Haematol. 38:281-290.

24. Cook, J. D., M. Layrisse, and C. A. Finch. 1969. The measurement of iron absorption. Blood. 33:421-429.

25. Walters, G. O., A. Jacobs, M. Worwood, D. Trevett, and W. Thomson. 1975. Iron absorption in normal subjects and patients with idiopathic haemochromatosis: relationship with serum ferritin concentration. Gut. 16:188-192.

26. Halliday, J. W., U. Mack, and L. W. Powell. 1978. Duodenal ferritin content and structure: relationship with body iron stores in man. Arch. Intern. Med. 138:1109-1113.

27. Powell, L. W., C. B. Campbell, and E. Wilson. 1970. Intestinal mucosal uptake of iron and iron retention in idiopathic haemochromatosis as evidence for a mucosal abnormality. Gut. 11:727-731.

28. Bothwell, T. H., R. W. Charlton, J. D. Cook, and C. A. Finch. 1979. In Iron Metabolism in Man. editors. Blackwell Scientific Publishers, Oxford. 1-576.

29. Huebers, H., E. Huebers, and W. Forth. 1971. Binding of iron to a non-ferritin protein in the mucosal cells of normal and iron-deficient rats during absorption. Life Sci. 10:1141-1148.

30. Halliday, J. W., L. W. Powell, and U. Mack. 1976. Iron absorption in the rat: the search for possible intestinal mucosal carriers. Br. J. Haematol. 34:237-250.

31. Pollack, S., and F. D. Lasky. 1976. Guinea pig intestinal iron binding protein. Biochem. Biophys. Res. Commun. 70:533-539.

32. Huebers, H. A., E. Huebers, E. Csiba, W. Rummel, and C. A. Finch. 1983. The significance of transferrin for intestinal iron absorption. Blood. 61:283-290.

33. Osterloh, K. R., R. J. Simpson, and T. J. Peters. 1987. The role of mucosal transferrin in intestinal iron absorption. Br. J. Haematol. 65:1-3.

34. Simpson, R. J., K. R. Osterloh, K. B. Raja, S. D. Snape, and T. J. Peters. 1986. Studies on the role of transferrin and endocytosis in the uptake of $\mathrm{Fe}^{3+}$ from $\mathrm{Fe}$-nitrilotriacetate by mouse duodenum. Biochim. Biophys. Acta. 884:166-171.

35. Cox, T. M., J. Mazurier, G. Spik, J. Montreuil, and T. J. Peters. 1979. Iron binding proteins and influx of iron across the duodenal brush border. Evidence for specific lactotransferrin receptors in the human intestine. Biochim. Biophys. Acta. 588:120-128.

36. Parmley, R. T., J. C. Barton, and M. E. Conrad. 1985. Ultrastructural localization of transferrin, transferrin receptor, and ironbinding sites on human placental and duodenal microvilli. Br. J. Haematol. 60:81-89.
37. Banerjee, D., P. R. Flanagan, J. Cluett, and L. S. Valberg. 1986. Transferrin receptors in the human gastrointestinal tract. Relationship to body iron stores. Gastroenterology. 91:861-869.

38. Osterloh, K., K. Schumann, C. Ehtechami, and W. Forth. 1985. Transferrin in isolated cells from rat duodenum and jejunum. Blut. 51:41-47.

39. Sciot, R., A. C. Paterson, den.Oord.J. J. Van, and V. J. Desmet. 1987. Lack of hepatic transferrin receptor expression in hemochromatosis. Hepatology (Baltimore). 7:831-837.

40. Hahn, P. F., W. F. Bale, and J. F. Ross. 1943. Radioactive iron absorption by gastro-intestinal tract: influence of anemia, anoxia, and antecedent feeding distribution in growing dogs. J. Exp. Med. 78:169188.

41. Theil, E. C. 1987. Ferritin: structure, gene regulation, and cellular function in animals, plants, and microorganisms. Annu. Rev. Biochem. 56:289-315.

42. Jacobs, A. 1985. Ferritin: an interim review. Curr. Top. Hematol. 5:25-62.

43. Arosio, P., T. G. Adelman, and J. W. Drysdale. 1978. On ferritin heterogeneity. Further evidence for heteropolymers. J. Biol. Chem. 253:4451-4458.

44. Boyd, D., C. Vecoli, D. M. Belcher, S. K. Jain, and J. W. Drysdale. 1985. Structural and functional relationships of human ferritin $\mathrm{H}$ and $\mathrm{L}$ chains deduced from cDNA clones. J. Biol. Chem. 260:11755-11761.

45. Matzner, Y., C. Hershko, A. Polliack, A. M. Konijn, and G. Izak. 1979. Suppressive effect of ferritin on in vitro lymphocyte function. Br. J. Haematol. 42:345-353.

46. Hann, H. W., M. W. Stahlhut, and L. C. Chung. 1984. Inhibitory effects of isoferritins from tumour and non-tumour tissues on E-rosette formation Letter to the editor. Lancet. 1:43.

47. Broxmeyer, H. E., J. Bognacki, M. H. Dorner, and M. de Sousa. 1981. Identification of leukemia-associated inhibitory activity as acidic isoferritins. A regulatory role for acidic isoferritins in the production of granulocytes and macrophages. J. Exp. Med. 153:1426-1444.

48. Dezza, L., M. Cazzola, W. Piacibello, P. Arosio, S. Levi, and M. Aglietta. 1986. Effect of acidic and basic isoferritins on in vitro growth of human granulocyte-monocyte progenitors. Blood. 67:789-795.

49. Blight, G. D., and E. H. Morgan. 1983. Ferritin and iron uptake by reticulocytes. Br. J. Haematol. 55:59-71.

50. Ulvik, R. J. 1982. Relevance of ferritin-binding sites on isolated mitochondria to the mobilization of iron from ferritin. Biochim. Biophys. Acta. 715:42-51.

51. Crosby, W. H. 1963. The control of iron balance by the intestinal mucosa. Blood. 22:441-449.

52. Beamish, M. R., R. Walker, F. Miller, M. Worwood, A. Jacobs, R. Williams, and A. Corrigall. 1974. Transferrin iron, chelatable iron and ferritin in idiopathic haemochromatosis. Br. J. Haematol. 27:219-228.

53. McGill, J. R., S. L. Naylor, A. Y. Sakaguchi, C. M. Moore, D. Boyd, K. J. Barrett, T. B. Shows, and J. W. Drysdale. 1987. Human ferritin $\mathrm{H}$ and $\mathrm{L}$ sequences lie on ten different chromosomes. Hum. Genet. 76:66-72. 